\title{
Iron Overload, CTCAE
}

National Cancer Institute

\section{Source}

National Cancer Institute. Iron Overload, CT CAE. NCI Thesaurus. Code C55993.

A disorder characterized by accumulation of iron in the tissues. 